\title{
AKSELERASI PENINGKATAN KOMPETENSI PENDIDIK DAN TENAGA KEPENDIDIKAN NONFORMAL
}

\author{
Enceng Mulyana*
}

\begin{abstract}
This article discusses various steps to increase the competence of PTK-PNF. First, it describes the roles of non-formal education in the national education system and the existing problems in the non-formal education. Then, the strategies to accelerate the competencies of PTK-PNF are introduced to cover the basic competencies and mapping of PTK-PNF. Further, the model of acceleration and need analysis to improve the competencies of PTK-PNF and the model of controlling the quality of the competence are elaborated and a set of controlling principles are identified. The article concludes that accelerating the competencies of PTK-PNF is an urgent need and can not be avoided to achieve the objectives of national education. This could be done through pre-service training, inand on-service trainings or distance learning programs. Total Quality Management and Professional Approach are recommended to be implemented continuously in each program.
\end{abstract}

Key words: non-formal education, competence, need analysis, acceleration models.

\section{PENDAHULUAN}

\section{Dasar Pijakan}

Pendidikan nonformal sebagai sub Sistem Pendidikan Nasional sesuai dengan UU No. 20/2003 tentang Sistem Pendidikan Nasional untuk kepentingan masa depan menuntut aktivitas yang tidak terhenti dalam memecahkan berbagai persoalan hidup, karena sebagai makhluk, manusia adalah citra yang tidak pernah selesai. Keberhasilan hari kemarin adalah awal perjuangan hari ini, keberhasilan hari ini adalah awal perjuangan besok, demikian seterusnya setiap persoalan menuntut pemecahan, dan setiap hasil pemecahan masalah tersebut tidak berarti telah selesai, selalu timbul persoalan dengan warna baru yang menuntut wawasan baru pula. Proses untuk mampu mengantisipasi permasalahan tidak lain dengan belajar sepanjang hayat, antara lain melalui jalur pendidikan nonformal.

Masa depan bangsa sangat ditentukan oleh proses belajarnya sendiri yang mengandung makna. Dengan belajar yang berasaskan pendidikan sepanjang hayat akan terjadi perubahan yang bisa memiliki predikat perbaikan prestasi. Perolehan perubahan sikap/laku perlu dibantu dengan memberi kesempatan untuk berpengalaman. Dalam hal ini proses belajar pendidikan nonformal akan sangat memberikan banyak kesempatan.

\footnotetext{
* Guru Besar \& Ketua LPM Universitas Pendidikan Indonesia
}

Masa depan bangsa melalui alternatif pendidikan nonformal tidak lain mempersiapkan seseorang untuk mampu mendewasakan atau memandirikan dirinya sendiri. Sikap kemandirian terwujud dalam kebiasaan berpikir dan belajar. Dengan berpikir dan berlatih berarti mempertahankan eksistensi diri.

Pendidikan nonformal untuk masa depan yang ceria berarti manusia akan melakukan proses belajar, mengkaji, menginterprestasi, menganalisis, belajar tentang apa yang berkenan dengan pemberian makna dari kehidupan seseorang, di mana saja, bilamana saja, dan dari sumber belajar manapun yang menggugah nurani kita guna mempertahankan eksistensi manusia menghadapi gejolak dunia dalam era globalisasi.

Berdasarkan uraian di atas pendidikan nonformal mengandung makna membelajarkan yang berarti membuat seseorang mau dan gemar belajar terus menerus sepanjang hayat, serta mampu menerapkan apa yang diperolehnya di dalam kehidupan dan untuk sumber penghidupannya. Makna pembelajaran itu sendiri mengandung pengertian: learning to know, learning to do, learning to be, and learning to live together (D. Sudjana, 2004).

Berdasarkan konsep di atas dapat dikatakan bahwa upaya penataan bentuk-bentuk kegiatan pendidikan nonformal untuk kepentingan masa depan sangat dituntut kejelian dalam memberikan makna terhadap prinsip tersebut yang muncul di dalam aktivitas nyata oleh PTK-PNF. 


\section{PEMBAHASAN}

\section{Beberapa Permasalahan Pendidikan Dalam Konteks PNF}

Kondisi objektif dunia pendidikan di Indonesia dewasa ini sesungguhnya masih menghadapi beberapa permasalahan mendasar. Fenomena menunjukkan bahwa tidak semua penduduk usia pendidikan (sejak usia dini sampai dewasa) terlayani oleh satuan dan jenjang pendidikan nonformal. Kasus di Indonesia memberi gambaran bahwa sebagian besar penduduk usia pendidikan tidak memperoleh kesempatan mengikuti pendidikan formal. Menurut Balitbang Diknas dalam Indonesia-educational Statistic in Brief (2000/ 2002), digambarkan bahwa jumlah anak usia dini, usia sekolah dasar, usia sekolah menengah pertama, usia sekolah menengah atas, dan usia perguruan tinggi adalah sebagai berikut.

Anak usia dini yang tak terlayani pendidikan formal dan nonformal paling besar jumlahnya $(72,05 \%)$. Jumlah anak usia sekolah dasar yang belum tertampung adalah sekitar $5,5 \%$ yang disebabkan terutama oleh gerakan wajib belajar Dikdas 9 Tahun. Sedangkan penduduk usia sekolah yang tidak terlayani pendidikan formal dan nonformal pada jenjang atau setara SLTP, SLTA, dan Perguruan Tinggi, masingmasing sekitar $44,2 \% ; 85,6 \%$; dan $87,9 \%$. Jumlah semua penduduk usia pendidikan sejak anak usia dini sampai dengan usia perguruan tinggi yang

Tujuan dan kajian filosofis
humanistik tersebut
memberikan kejelasan bahwa
tujuan pendidikan nonformal
adalah mengembangkan
seoptimal mungkin kemampuan
dan potensi sasaran didik
pendidikan nonformal,
sehingga pada akhirnya dapat
meningkatkan dan menolong
dirinya sendiri.
terlayani oleh pendidikan formal sekitar $44,96 \%$, sedangkan yang tidak terlayani jalur pendidikan formal dan nonformal ternyata lebih besar yaitu sekitar $55,04 \%$.

Angka putus sekolah ternyata masih tinggi. Rata-rata jumlah anak putus sekolah dasar pada kelas 1-3 sekitar 200.000 sampai 300.000 orang setiap tahun. Jumlah anak putus sekolah ini termasuk kepada kelompok penduduk buta aksara yang banyaknya sekitar 18,7 juta. Dalam waktu 23 tahun sejak tahun 1970 sampai dengan 1993, diduga 33,8 juta murid SD dan 10,6 juta siswa SLTP mengalami putus sekolah (Fasli Jalal, 2003).

Adapun tantangan pendidikan akhir tahun 2006 bahwa rata-rata 6,2 tahun. APK SMP/SMK/MTs/ SMPLB/Paket B $88,68 \%$. APK SMA/SMK/MA/ SMALB/ Paket C 56,22\%. Buta aksara 9,11\% (Dodi Nandika, 2007).
Permasalahan lain dalam dunia PNF bidang ketenagaan ternyata jumlah tenaga pendidik dan kependidikan PNF tahun 2006 masih memprihatinkan. Misalnya di Jawa Barat khususnya KF (4.594 orang), Paket A 254 orang, Paket B 698 orang, Paket C 318 orang. Angka tersebut belum diketahui berapa banyak yang merangkap dari Paket $B$ ke Paket $A$ atau Paket $C$ ke Paket B (Subdin PLS Dinas Pendidikan Jabar, 2006).

Sementara itu latar belakang pendidikan yang dimiliki relatif bervariasi. Sebagai contoh, Provinsi Jawa Barat khususnya Kabupaten Subang, Sumedang, Cirebon, dan Tasikmalaya tahun 2006 bahwa pendidikan dan tenaga kependidikan PNF 77 orang berpendidikan SMA, setara Diploma 69 orang dan S1 200 orang (BPPLS Reg. II Tahun 2007). Kondisi seperti ini memberi peluang untuk ditindaklanjuti melalui program akselerasi ketenagaan baik jumlah maupun mutu yang belum diketahui bahwa kinerja yang ada pada tenaga yang bersangkutan.

Strategi Percepatan Peningkatan Kompetensi Pendidikan dan Tenaga Kependidikan PNF

1. Kompetensi Dasar yang Harus Dikembangkan

Dasar pijakan bagi seorang petugas PNF dalam peranannya adalah berbagai ketentuan/aturan formal yang mengatur peranan diri yang tertuang dalam tugas pokok dan fungsi (tupoksi) harus dipahami dan dilaksanakan secara seksama secara keseluruhan tidak parsial. Tata aturan ini akan mewarnai terhadap kompetensi diri PTK-PNF yakni: (a) information giver dalam makna memiliki kemampuan dalam mengumpulkan berbagai informasi kepada pihakpihak yang bersangkutan secara jelas, benar, tepat sehingga menjadikan kelompok sasaran memiliki suatu pengetahuan, pengertian dan pemahaman yang sama sehingga terdapat persepsi yang sama antara petugas dengan kelompok sasaran tentang misi yang disampaikan; (b) process helper dalam makna memberi bantuan terhadap khalayak sasaran dalam melaksanakan proses kegiatan yang dilaksanakan sehingga khalayak sasaran mendapat kemudahan dan tak mengalami/salah melakukan penyimpangan dari aturan yang berlaku sehingga pencapaian tujuan tercapai dengan lancar; (c) solution giver dalam makna memberikan alternatif pemecahan masalah yang 
dihadapi oleh kelompok sasaran jika yang bersangkutanmengalami kesulitan dalam melaksanakan program kegiatan dan keempat; dan (d) resources linker dalam makna membantu khalayak sasaran dalam melakukan penggalian potensi dan pemanfaatannya baik potensi manusiawi maupun potensi alami dan potensi kelembagaan dengan membantu membangun jaringan (networking) atau akses ke dunia luar/akses eksternal.

\section{Pemetaan Ketenagaan}

Langkah awal yang mulai diterapkan dalam menyusun rancangan kerja atau program kegiatan adalah identifikasi masalah dan sumber pembelajaran. Langkah ini dimaksudkan untuk memperoleh gambaran nyata kondisi objektif ketenagaan pendidik dan tenaga kependidikan nonformal baik secara kuantitatif maupun kualitatif sehingga diperoleh data/pemetaan ketenagaan secara akurat. Data ini untuk dijadikan bahan atau pangkal tolak dalam rangka menyusun suatu perencanaan atau sebagai rujukan awal di dalam menetapkan kebijakan/strategi yang akan ditempuh baik dalam skala mikro maupun makro program akselersi peningkatan kemampuan kompetansi PTKPNF. Langkah awal ini bisa digunakan dengan menggunakan model pendekatan SWOT (Strong, Weakness, Opportunity, Treath). Sebagai rujukan bisa dicermati Kerangka Pemikiran Pengembangan Kebijakan dan Program Pembangunan Pendidikan Nasional (2005-2009) sebagai berikut.

Kerangka Pemikiran Pengembangan Kebijakan dan Program Pembangunan Pendidikan Nasional Tahun 2005-2009

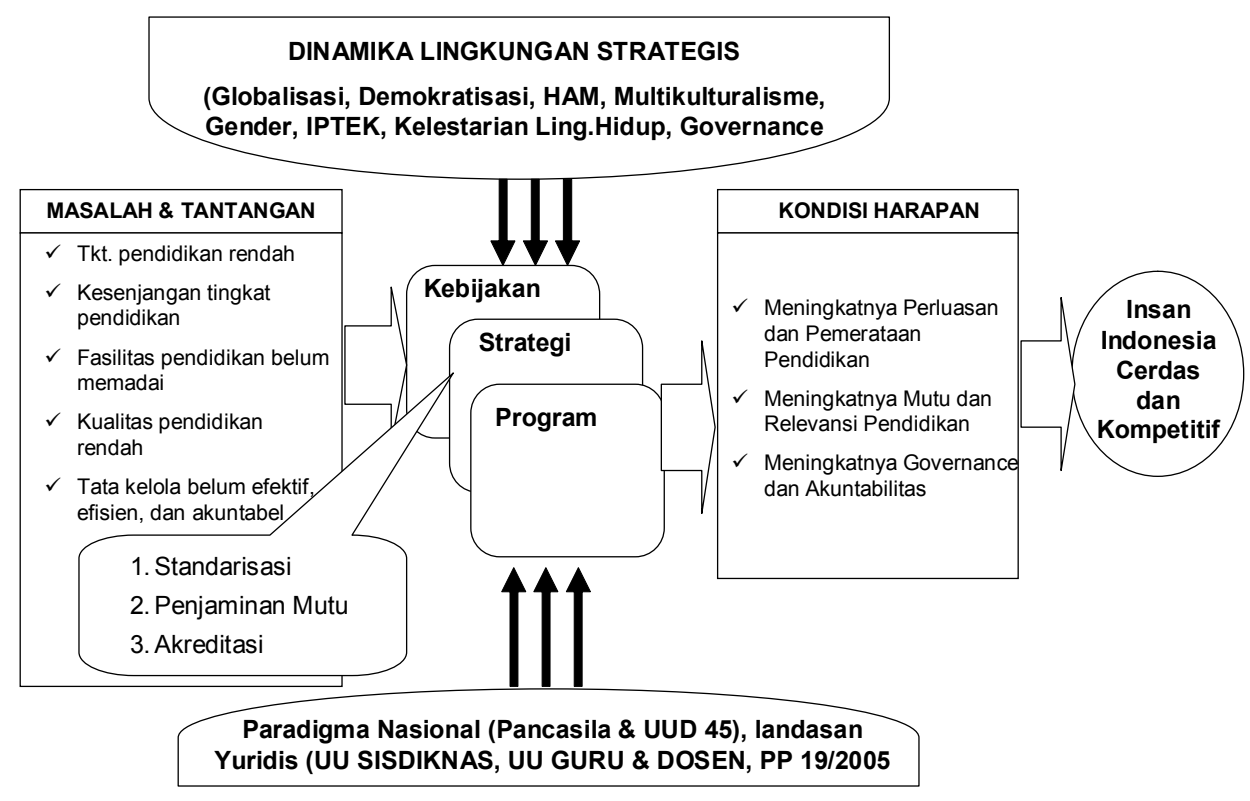

Gambar 1.Kerangka Pemikiran Pengembangan Kebijakan dan Program Pembangunan Pendidikan Nasional 2005-2009

Paradigma di atas merupakan kebijakan Departemen Pendidikan Nasional Tahun 2005-2009 yang memandang bahwa dinamika globalisasi demokratisasi perkembangan iptek dan Governance menjadi dasar dalam menetapkan kebijakan nasional bidang pendidikan. Kebijakan nasional bidang pendidikan ini ditata dengan memperhitungkan sejumlah masalah dan tantangan yang meliputi aspek pemerataan pendidikan, masalah mutu, dan tata kelola (governance) dengan harapan adanya kondisi yang semakin meningkat sesuai dengan harapan sehingga tahun 2009 idealnya terwujud insan Indonesia yang cerdas dan kompetitif. Kebijakan ini dijabarkan melalui rencana strategi dalam wujud standarisasi, akreditasi, dan penjaminan mutu pendidikan baik pada jalur pendidikan formal maupun pendidikan nonformal yang diatur dengan Peraturan Pemerintah dengan segala kelengkapan aturan sebagai penjabarannya.

Adapun program yang dicanangkan ditempuh atau diwujudkan melalui 15 program utama yang dikemas melalui subsistem pendidikan formal dan subsistem pendidikan nonformal dan pendidikan informal. Di dalam program besar ini termasuk di dalamnya tata pamong dan sistem manajemen yang akurat. Keseluruhan kebijakan strategi dan program berdasarkan paradigma nasional (Pancasila, UUD 45, UU Sistem Pendidikan Nasional RI dan UU Guru dan Dosen serta PP No. 19/2005). 


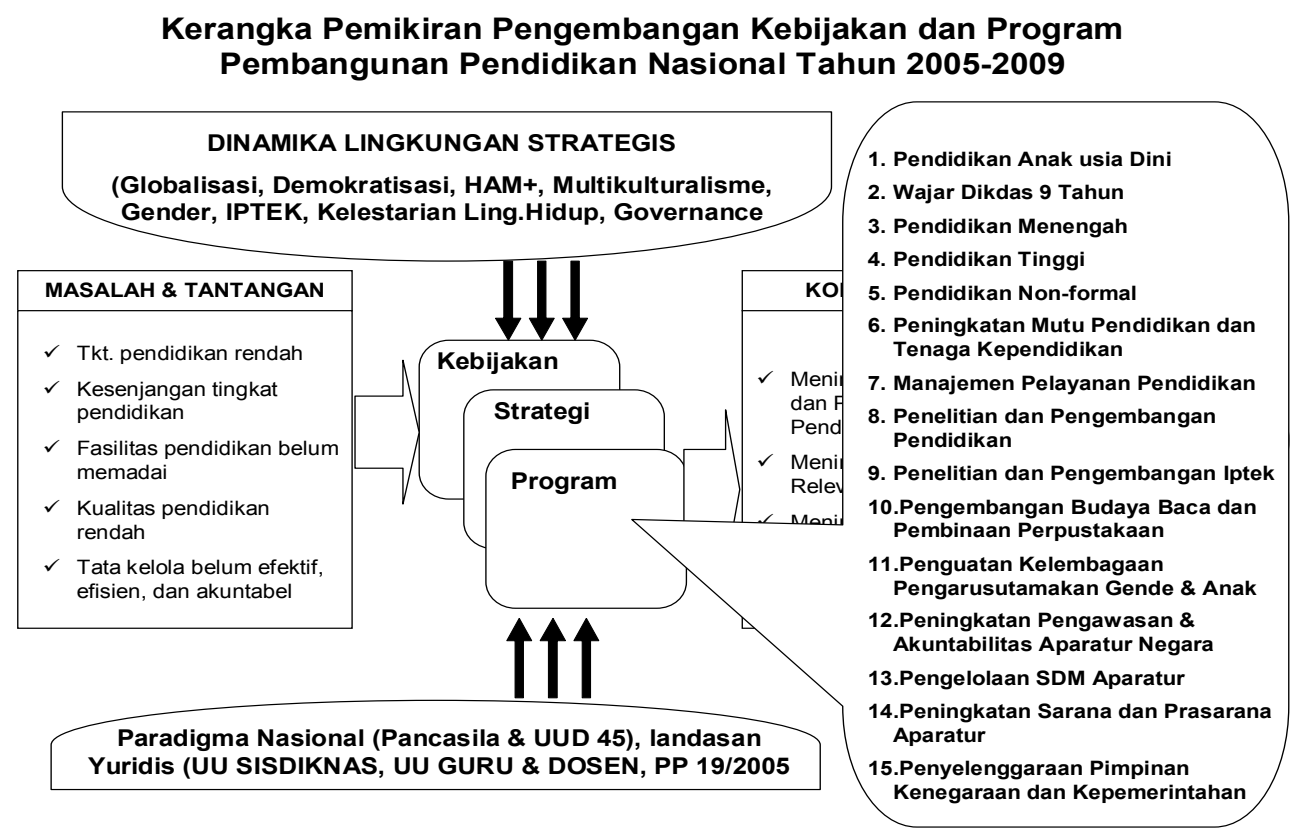

Gambar 2. Kerangka Pemikiran Pengembangan Kebijakan dan Program Pembangunan Pendidikan Nasional 2005-2009 (Dodi Nandika, Sekjen Depdiknas, 2007)

Kerangka pemikiran ini memerlukan tindak lanjut yang diawali dengan penataan kondisi objektif ketenagaan secara akurat. Artinya mutlak perlu ada penataan dan analisis data yang dilakukan oleh tim independen sebagai bahan titik awal dalam menyusun program akselerasi khususnya penataan di bidang nonformal.

\section{Model Akselerasi dan Analisis Kebutuhan Peningkatan Kompetensi PTK-PNF}

Berdasarkan langkah awal melalui identifikasi potensi ketenagaan yang tersedia maka format akselerasi peningkatan kompetensi PTK-PNF digambarkan sebagai berikut.

\section{FORMAT AKSELERASI PENINGKATAN KOMPETENSI PTK - PNF}

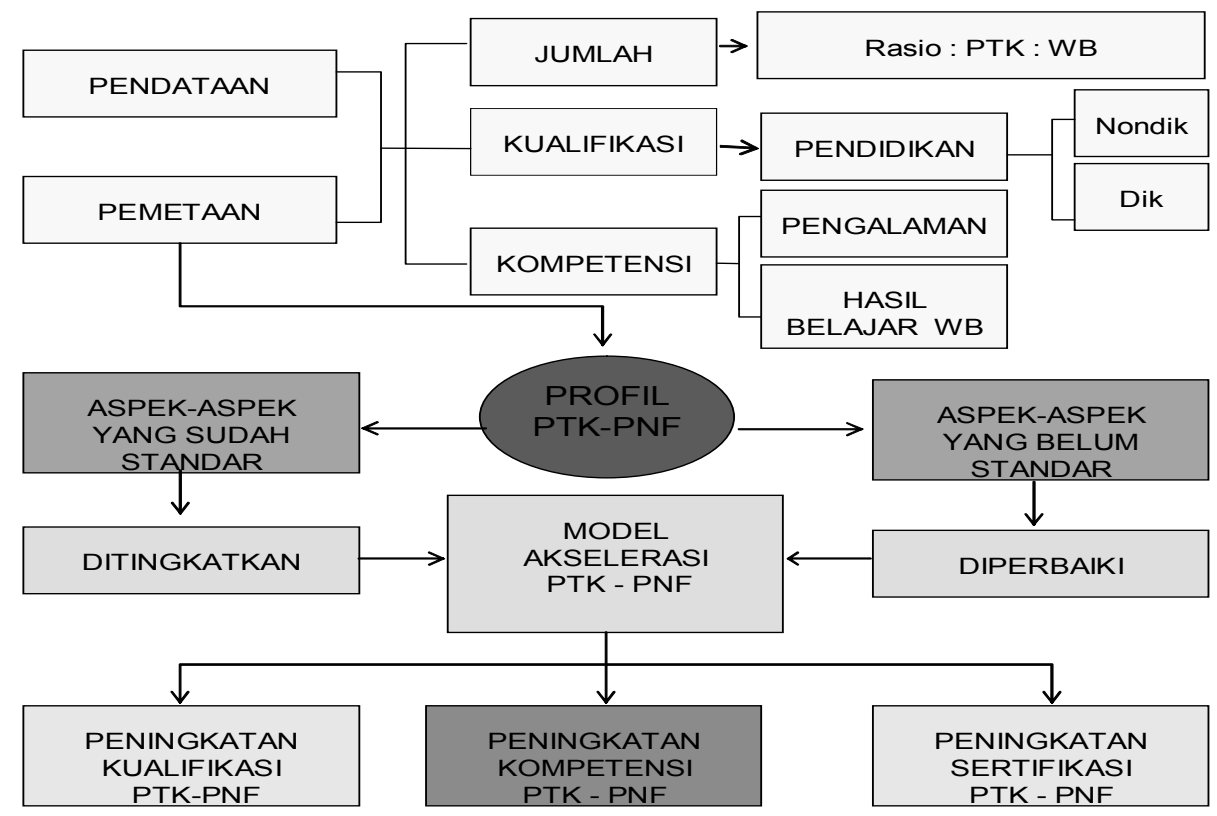

Gambar 3. Format Akselerasi Peningkatan Kompetensi PTK-PNF

Gambar di atas pada dasarnya memberikan petunjuk bahwa langkah awal dalam proses akselerasi peningkatan mutu PTK-PNF terlebih dahulu diperlukan informasi/data tentang profil PTK-PNF masa kini. Profil ini akan diketahui jika dilakukan pemetaan yang menjaring berbagai data baik jumlah maupun 
kualifikasinya sehingga diketahui pula rasio PTK-PNF dengan warga belajar. Di sisi lain akan diketahui pula latar belakang pendidikan, pengalaman termasuk hasil belajar. Dengan diketahui profil PTK-PNF akan ditemukan aspek-aspek yang sudah standar dan yang belum standar. Dengan demikian, ditemukan model akselerasi bagi yang telah standar ditingkatkan dan bagi yang belum standar diperbaiki melalui berbagai alternatif kemungkinan bentuk-bentuk pelayanan pendidikan/latihan yang disiapkan.

Dalam rangka implementasi model akselerasi peningkatan mutu PTK-PNF sebagai gambaran di atas maka format analisis kebutuhannya sebagai berikut.

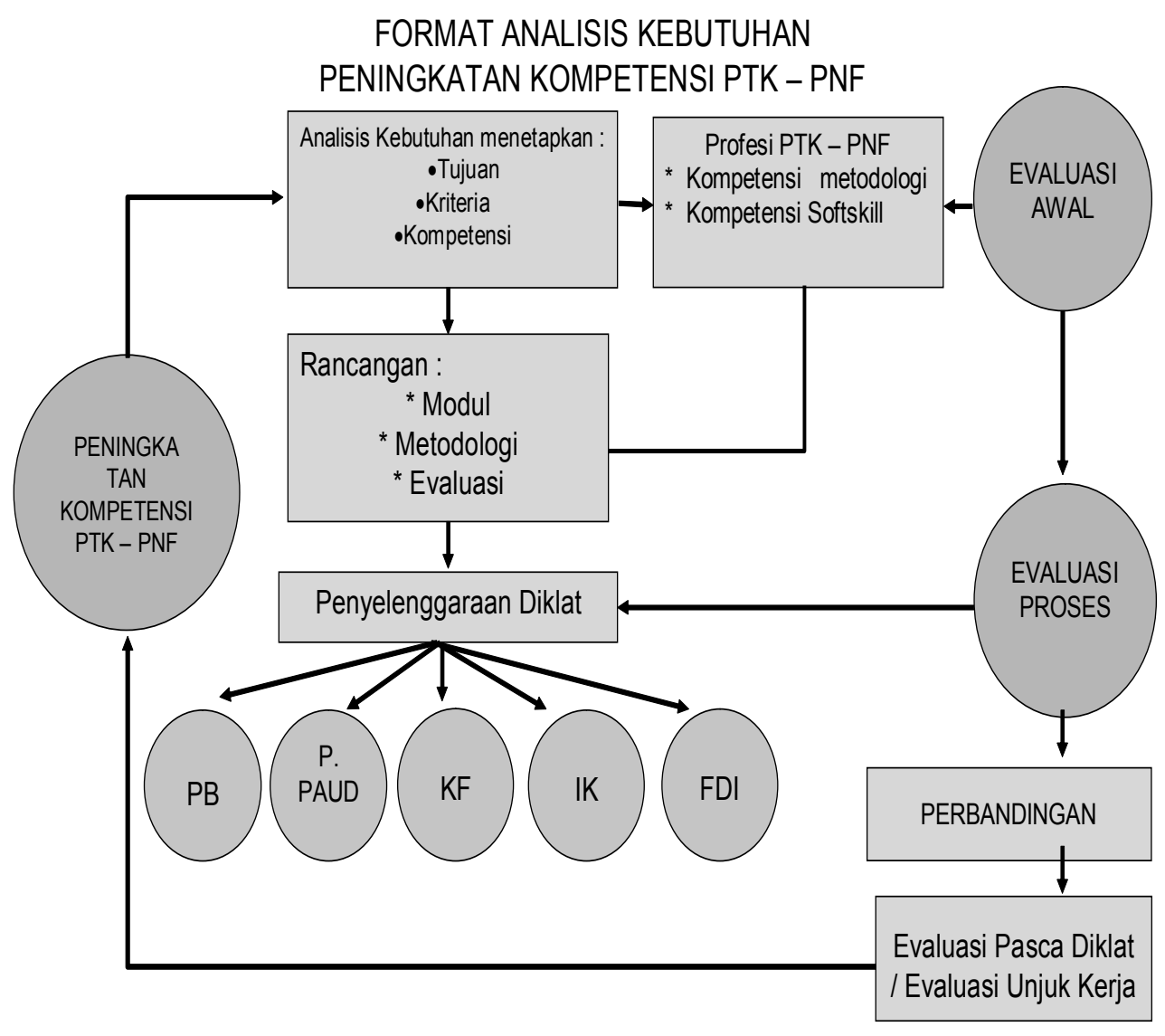

Gambar 4. Format Analisis Kebutuhan Peningkatan Kompetensi PTK-PNF

Alur pikir sebagaimana tergambarkan di atas pada hakekatnya dituntut terciptanya model, metodologi dan evaluasi peningkatan mutu PTK-PNF. Model tersebut akan terwujud setelah dilakukan analisis kebutuhan dan dirumuskanlah tujuan, kriteria dan kompetensi, metodologi dan kompetensi soft skill. Setelah model terbentuk barulah dilakukan diklat untuk berbagai kepentingan yang dilaksanakan dan ditindaklanjuti oleh evaluasi proses dan evaluasi hasil. Hasil evaluasi dimaksudkan sebagai bahan kajian untuk mengetahui berapa besar pengaruhnya terhadap peningkatan kompetensi yang diharapkan.

Model pelatihan yang sifatnya konvensional berupa pelatihan, diklat, workshop dan lain-lain, perlu disertai dengan monitoring dan evaluation (monev) secara berkelanjutan (sustainable) dengan model dampingan termasuk program (Belajar Jarak Jauh) untuk dipikirkan bagaimana kemungkinannya bisa dilaksanakan melalui pendidikan nonformal dengan sistem modul.

\section{Model Pengendalian Akselerasi Peningkatan Kompetensi PTK-PNF}

Pengendalian mutu kompetensi hendaknya digunakan antara lain dengan pendekatan Total Quality Management (TQM) dalam pendekatan ini terdapat empat komponen dasar pengendalian mutu yaitu: input, transformasi atau proses, output dan nilai bagi stakeholders. Pengendalian mutu untuk setiap kegiatan pada setiap komponen dasar dilakukan secara sistematis mencakup kegiatan penetapan standarisasi, studi, pengukuran, dan tingkatan koreksi.

Kegiatan pengendalian mutu ini dilakukan pada setiap tingkatan organisasi atau unit kerja sesuai dengan fungsinya yang berkaitan dengan komponen dasar pengendalian secara diagrammatis model sebagai berikut. 


\section{MODEL PENGENDALIAN AKSELERASI PENINGKATAN KOMPETENSI PTK - PNF}

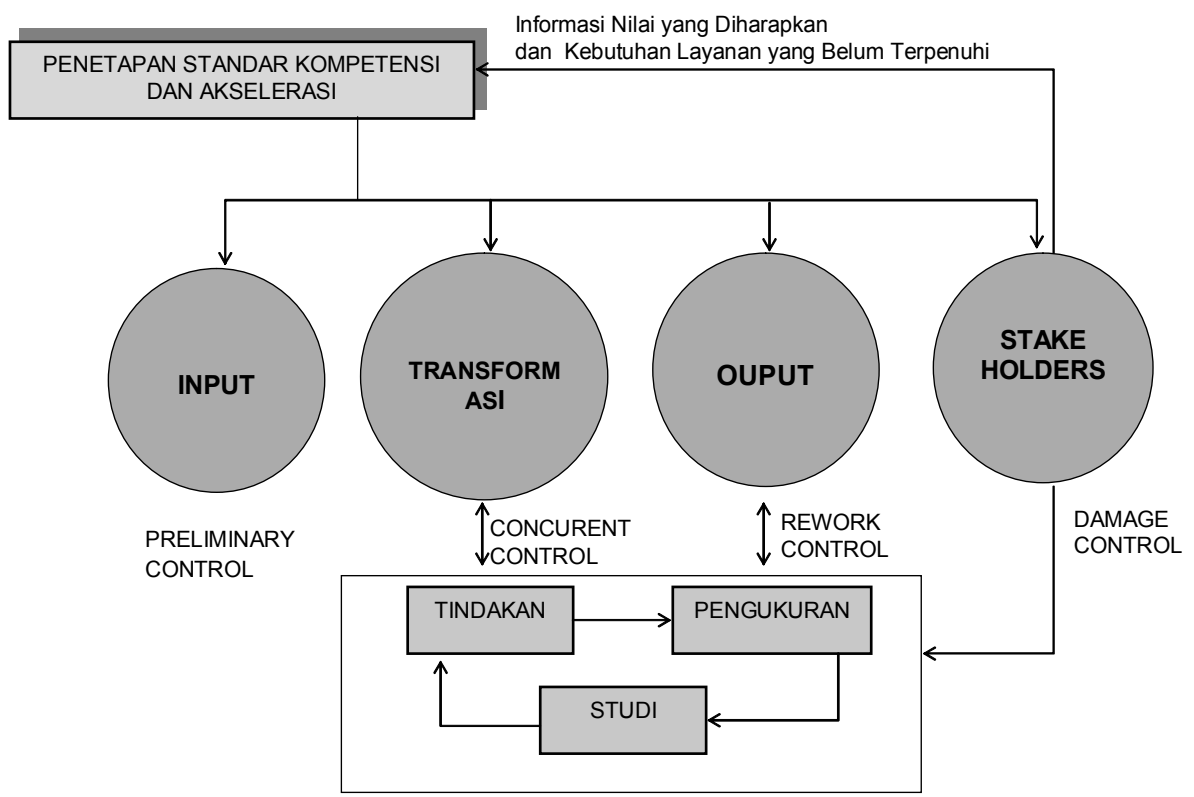

Gambar 5. Model Pengendalian Akselerasi Peningkatan Kompetensi PTK-PNF

Model pengendalian mutu peningkatan kompetensi PTK-PNF hendaknya ditetapkan terlebih dahulu standar kompetensinya setelah mempertimbangkan informasi nilai yang diharapkan dan kebutuhan layanan yang belum terpenuhi. Model ini menggunakan alur sistem input, transformasi (proses) dan output yang melibatkan unsur stakeholders.

Pada dasarnya kegiatan pengendalian mutu di atas menggambarkan pendekatan perbaikan mutu dengan fokus kajian yaitu: (1) preliminary control, bersifat preventif untuk menghindari mutu kompetensi yang tidak diinginkan dan produktif untuk mencapai kualitas kompetensi yang diharapkan (difokuskan pada input) dengan memperbaiki input berarti melakukan pengendalian terhadap komponen transformasi (proses), output, dan nilai bagi stakeholders; (2) concurrent control, dilakukan dalam pengendalian proses operasional pada tahap transformasi (proses); (3) rework control, dilakukan apabila butir 1 dan 2 mengalami kegagalan / berbagai hambatan (fokus pada output); (4) damage control, untuk meminimalkan dampak negatif dari tidak tercapainya target nilai (fokus pada stakeholders).

Adapun prinsip pengendalian sebagai berikut: (1) quality first, seluruh pikiran dan tindakan pimpinan pada berbagai tingkat organisasi/lembaga harus memprioritaskan mutu; (2) stakeholders-in, seluruh pikiran dan tindakan pimpinan pada berbagai tingkat organisasi/lembaga harus pada kepuasan stakeholders; (3) the next process is our stakeholders, setiap orang yang melaksanakan tugas harus menganggap pihak lain yang menggunakan hasil harus dipuaskan; (4) speak with data, dalam setiap tindakan harus berbasis analisis data yang relevan; (5) up stream management, pengambilan keputusan dalam akselerasi harus dilakukan secara partisipatlf. Ahirnya secara sistematis pola pikir akselerasi peningkatan mutu PTK-PNF dapat digambarkan sebagai berikut.

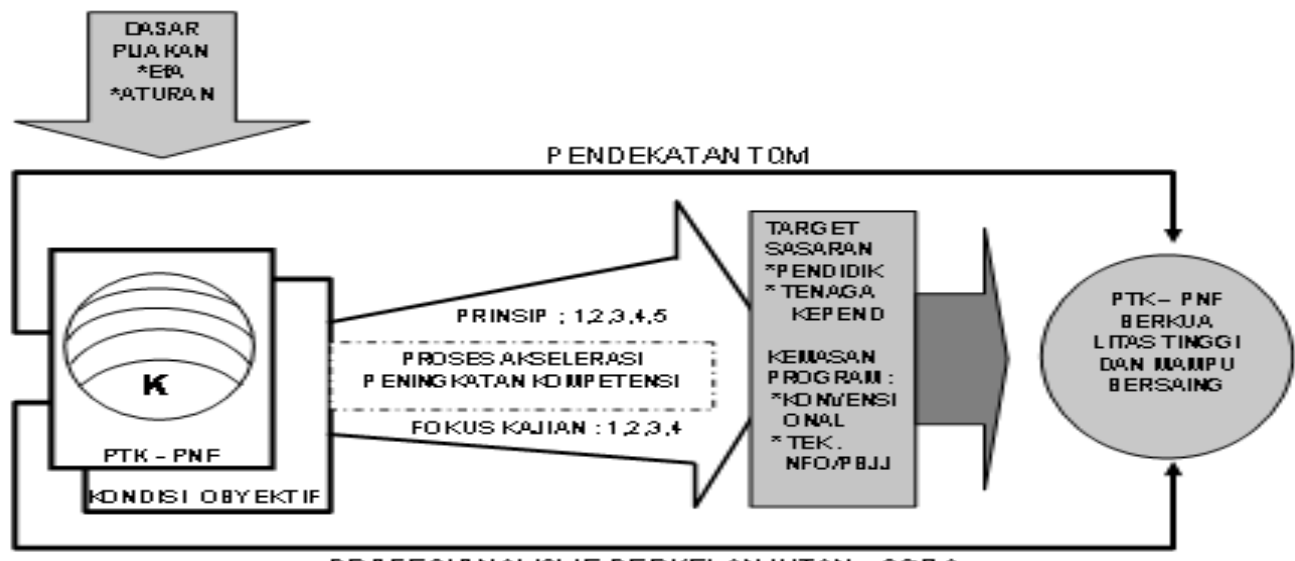

PROFESIONALISHA BERKELANJUTAN - SCDA

Gambar 6. Alur Pikir Akselerasi Peningkatan Kompetensi PTK-PNF 


\section{KESIMPULAN}

Bahwa akselerasi peningkatan kompetensi Pendidik dan Tenaga Kependidikan Nonformal (PTKPNF) dewasa ini merupakan tuntutan mutlak yang sesegera mungkin untuk dilaksanakan dalam rangka mencapai target dan pencapaian tujuan pendidikan nasional yang bermuara pada terbentuknya insan cerdas, kompetitif.

Proses kegiatan yang ditempuh kearah tersebut bisa melalui pelayanan pendekatan yang bersifat konvensional melalui berbagai jenis pelatihan, seminar, workshop, magang, yang semuanya merupan pelayanan yang bersifat inservice training. Upaya akselerasi dalam bentuk pelayanan pendidikan/ pengembangan sumber daya manusia, bisa ditempuh melalui Pendidikan Belajar Jarak Jauh (BJJ) dengan menggunakan sistem modul bahkan melalui ICT walaupun dalam hal ini masih memerlukan kajian kemungkinannya.

Demi mutu pelayanan pendidikan perlu dilakukan pendekatan Total Quality Management (TQM) dan pendekatan profesional secara sustainable dengan disertai Quality Control dalam setiap langkah kegiatan.

\section{DAFTAR PUSTAKA}

Jalal, F. (2003). Peran PAUD dalam PSDM, Loknas UPI.

Kartadina, S. (2006). Peranan UPI dalam merespon perkembangan kebutuhan PTK-PNF, Loknas UPI.

Mulyana, E. (2006). Trend PLS di masa depan, Jurnal

\section{PLS-UPI).}

Nandika, D. (2007). Kebijakan sistem nasional (orasi ilmiah wisuda STKIP siliwangi bandung).

Sudjana, D. (2007), Eksistensi dan prospek jurusan PLS, Manado.

UPI. (2006). Pedoman penjaminan mutu UPI. 